\title{
RESPONSE OF FABA BEAN YIELD TO INORGANIC, ORGANIC-N FERTILIZERS AND THEIR COMBINATION WITH SOME COMPOUNDS AS FOLIAR APPLICATIONS ON GROWTH, YIELD AND MINERAL COMPOSITION. \\ Abd El-Hameed, A.M. and S.H. Sarhan \\ Plant Nutrition, Soil, Water and Environment, Res. Inst., Agric. , Res. Center, Giza, Egypt.
}

\section{ABSTRACT}

Two field experiments were conducted at Qalabshu, Agriculture Research Station, during two successive seasons of 2006/2007 and 2007/2008. The work aimed to study the response of faba bean plant to inorganic \& organic-N and its combined fertilizers with some compounds as foliar applications on growth, yield and mineral composition.

It was found that :-

1 The foliar application of (N, P and $\mathrm{K})$ gave the highest mean values for yield with mixed plots ( $25 \%$ of mineral $+25 \%$ of FYM both of recommended doses), but the effect of inorganic \& organic- $\mathrm{N}$ and their combined gave the equal mean values of phytic acid concentrations with $\mathrm{N}, \mathrm{P}$ and $\mathrm{K}$ foliar application treatment.

2- The inorganic-N Fertilization (100\% mineral of recommended dose , $8 \mathrm{~kg} \mathrm{~N} / \mathrm{fed}$ ) gave the highest mean values of $\mathrm{N}$ and $\mathrm{K}$ - uptake, but the combined Fertilization gave the highest mean values of $\mathrm{P}$-uptake with $\mathrm{N}, \mathrm{P}$ and $\mathrm{K}$ foliar application treatment.

3- The inorganic- $\mathrm{N}$ fertilizer gave the highest mean values for Fe-uptake, but the organic-N fertilization (100\% of FYM of recommended dose , 10 ton/Fed) gave the highest mean values for $\mathrm{Zn}$, Mo and Co- uptake, in contrast, the combined Fertilizers gave the highest mean values for Mn- uptake, obtained with N.P and $\mathrm{K}$ foliar application treatment, except Co-uptake for the B, Mo and Co foliar applications treatment.

From these discussion, it could be concluded that the inorganic \& organic- $N$ and the combined Fertilization with the $(\mathrm{N}, \mathrm{P}, \mathrm{K})$ treatmeants as foliar application are important for obtaining a high and good quality in yield and its components, while, decreased phytic acid in seeds as the result of using yeast as fertilizer .

\section{INTRODUCTION}

In most developing countries legumes are often an integral part of agricultural ecosystems. Faba bean (Vicia Faba L.) is one of the most important legumes in Mediterranean agricultural area (Buttery et al., 1992). In Egypt, it consumed in huge quantities as human food or animal feed, since its dry seeds contain about $30 \%$ protein and $65 \%$ carbohydrates as main components (Omer et al., 1990). However, faba bean cultivated in Egypt are subjected to some problems such as high concentertion of phytic acid.

Concering the effect of foliar nutrition, several investigators reported that growth, total yield and mineral content of crops were markedly increased (Abd El-Hadi et al., 1986, Abd El-Hameed et al., 2003 and Sherif, 2003). Foliar nutrition of soya bean with NPK during early vegetative stages could result in increasing growth and higher yield (Hag and Mallarino, 1998) . 
Mourad et al., 2004, indicated that the foliar application of Fe, $\mathrm{Zn}$ and $\mathrm{Mn}$ on Faba bean individually or in double or triple combination increased yield and its components. Janec zek et al., 2004, reported that the foliar application of $\mathrm{B}$, Mo and $\mathrm{Co}$ on bean increased number of pods / plant and number of seed / pod compard with control. Foliar application of N.A.A as growth regulator increase pod length, yield and fruit number per plant yield of yard long bean, (Resmi and Gopolokrishnan, 2004. Fathy and Farid, 1996, reported that the number of pods, fruit setting and total yield of common bean plants increased due to application of backer's yeast.

Nitrogen plays a vital nutritional and physiological role in plant and is also unique among the mineral nutrients where it can be absorbed by plants in two distinct forms, either as the $\mathrm{NO}_{3}{ }^{-}$or the $\mathrm{NH}_{4}{ }^{+}$, thus depend on Fertilizers rate of inorganic \& organic nitrogen , Irshad et al.,2002.

This work aimed to study the response of faba bean plants to inorganic \& organic- $\mathrm{N}$ fertilizers with some compounds as foliar applications through studing their effect on growth, yield and mineral compositions and decrease phytic acid concentration as well .

\section{MATERIALS AND METHODS}

Two field experiments were established to fulfill the objectives of present work as follows :

Loction : At Agriculture Research station of Qalabshu, Dakahlia Governorate during 2006/2007 and 2007/2008 seasons.

Soil :The representative surface soil samples $(0-30 \mathrm{~cm})$ performance of the experiment with some characteristics of the soil analysis were determined according to Black,(1982) indicated in Table 1.

Table 1: Some physical and chemical properties of the experimental soil.

\begin{tabular}{|c|c|c|c|c|c|c|c|c|c|c|c|c|c|c|c|}
\hline iand & silt & day & & O.M & $\mathrm{CaCO}_{3}$ & & $E C_{e}$ & & & & & & & & \\
\hline or & $\%$ & $\rightarrow$ & & $\%$ & $\%$ & pH & & $\mathbf{N}$ & $\mathbf{P}$ & $\mathbf{K}$ & $\mathrm{Fe}$ & $\angle \mathbf{n}$ & Mn & B & Mo \\
\hline$\$ 1.1 \varepsilon$ & & 8.65 & $\begin{array}{l}\text { sandy } \\
\text { loam }\end{array}$ & 0.50 & 1.96 & 8.31 & 1.95 & & 1.0 & 19 & 2.5 & 0.5 & 1.0 & & 0. \\
\hline
\end{tabular}

Studied crop : Faba bean (Vicia Faba L.) Sakha $461(40 \mathrm{~kg} / \mathrm{Fed}$.) was obtained from Agric. Res. Center. The planting date $3^{\text {rd }}$ of November to the two seasons.

Experimental plot : $4 \times 3 \mathrm{~m}=12 \mathrm{~m}^{2}$ was designed in complete randomized design.

Experimental treatments : the experiment plot involved 27 treatments in addition of 3control for each(mineral,FYM,mixed). Each treatment was replicated three times, so the total treatments equal 90 plots. The detailed experimental treatments were as follows.

The main plots of nitrogen Fertilizers :

- $50 \%$ of nitrogen / recommended dose $(8 \mathrm{~kg} \mathrm{~N} / \mathrm{Fed})$ from the urea fertilizer $(46.5 \%)$.

- $50 \%$ of FYM recommended dose (5 Ton/Fed). 
- $25 \%$ of nitrogen recommended dose $+25 \%$ of FYM recommended dose. The treatments of foliar applications were as following:

1- Control ( destilled water).

2- N, P and K (300, 150 and 100ppm, respectively).

3- Fe, $\mathrm{Zn}$ and $\mathrm{Mn}$ (50, 100 and 50ppm ,respectively).

4- B, Mo and Co (50, 25 and 10ppm, respectively).

5- Mixed of treatments (2, 3 and 4). M1

6- N.A.A $(0.8 \mathrm{gm} / \mathrm{L}$ Naphthalene Acetic Acid).

7- Sucrose $(4 \mathrm{gm} / \mathrm{L})$.

8- Yeast $(8 \mathrm{gm} / \mathrm{L})$.

9- Mixed of treatments ( 6,7 and 8$)$. M2.

10- Mixed if (2, 3 and 4) with mixed of $(6,7$ and 8$) \mathrm{M} 1,+\mathrm{M} 2-$

A basal dose of $\mathrm{N}, \mathrm{P}, \mathrm{K}$ [16kg N/Fed] as urea, $15 \mathrm{~kg} \mathrm{P} \mathrm{P}_{2} \mathrm{O}_{5} / \mathrm{Fed}$ as superphosphate $(15.5 \%)$ and $48 \mathrm{~kg} \mathrm{~K}_{2} \mathrm{O} / \mathrm{Fed}$ as potassium sulphate $(48 \%)$. $\mathrm{Fe}, \mathrm{Zn}, \mathrm{Mn}, \mathrm{B}, \mathrm{Mo}$ and $\mathrm{Cu}$ were used as $\mathrm{FeSO}_{4}, \mathrm{ZnSO}_{4} . \mathrm{H}_{2} \mathrm{O}, \mathrm{MnSO}_{4} \cdot \mathrm{H}_{2} \mathrm{O}$, Boric acid, $\left(\mathrm{NH}_{4}\right)_{6} \mathrm{Mo}_{7} \mathrm{O}_{24} .4 \mathrm{H}_{2} \mathrm{O}$ and $\mathrm{CuSO}_{4} .7 \mathrm{H}_{2} \mathrm{O}$.

Dry pods were Picked up, seeds were weight and calculated by ardab/Fed. Samples of the dried seeds were ground and wet digested by $\mathrm{HC}_{10}-\mathrm{H}_{2} \mathrm{SO}_{4}$ mixture according to Petter Burgski,1968) to determined the total $\mathrm{N}, \mathrm{P}, \mathrm{K}, \mathrm{Fe}, \mathrm{Zn}, \mathrm{Mn}, \mathrm{B}, \mathrm{Mo}$ and $\mathrm{Co}$ in acidic extract, phytic acid was determined colorimetrically using spectrophotometer as discribed by Wheeler and Ferrel (1971).

A combined analysis of collected data for both seasons was done using the analysis of variance technique according to Gomez and Gomez (1984).

\section{RESULTS AND DISCUSSION}

\section{Faba bean grain yield :}

The effect of Foliar application treatments with inorganic \& organic-N Fertilizers and its combination on faba bean grain yield (ardab/Fed) of the mean values in two growing seasons are presented in Table 2. The results indicate that the grain yield obtained from foliar application treatment of $\mathrm{N}$, Pand K (300, 150 and 100ppm for N, P and K, respectively) gave the highest grain yield $=16.79($ ardab/fed) as average and higher than the other treatments and it was significant. It was cleared that NPK treatments gave fertility

The heighest values for mineral and mixed plots ( main plots) the values were 16.55 and $17.63 \mathrm{ardab} / \mathrm{fed}$, respectively, while $\mathrm{B}$, Mo and $\mathrm{Cu}$ treatments gave the heighest values for FYM plot. But the mixed treatments (mixed 1 , mixed 2 and mixed 3 ) gave a significant reduction in the grain yield. These results are confirmed with those repoted by Aly, (2003).

In respect of defferences average values between, mineral, FYM and mixed main plots were highly significantand follow this order mixed $>$ mineral $>$ FYM (13.66, 11.07 and 10.60, respectively. And the average grain yield for mineral and FYM treatments were $18.96 \%$ and $21.96 \%$ less than that of its combined treatment, respectively. 
It can notice that from the same Table (2), using N. A. A, sucrose and yeast, respectively or mixed have no effect in grain yield.

These results are confirmed to those reported by Tolba et al., (2003).

From the obtained results of this experiment, it can be concluded that applying $\mathrm{N}, \mathrm{P}$ and $\mathrm{K}$ Foliar application treatment with their combined treatments are the best treatment.

Table 2: Effect of inorganic \& organic-N and combined fertilizers with

\begin{tabular}{|c|c|c|c|c|c|c|c|c|}
\hline $\begin{array}{c}\text { Foliar } \\
\text { Treatments }\end{array}$ & \multicolumn{4}{|c|}{ Yield (ardab/Fed) } & \multicolumn{4}{c|}{ Phytic acid \% } \\
\hline mineral & FYM & Mixed & Ave. & mineral & FYM & Mixed & Ave. \\
\hline Control & 10.97 & .46 & 12.90 & 8.55 & 0.40 & 0.40 & 0.40 & 0.38 \\
\hline N,P,K & 16.55 & 11.46 & 17.63 & 16.79 & 0.53 & 0.42 & 0.43 & 0.55 \\
\hline Fe,Zn,Mn & 14.13 & 11.29 & 16.07 & 15.73 & 0.46 & 0.44 & 0.45 & 0.46 \\
\hline B,Mo,Co & 13.41 & 15.41 & 16.17 & 15.01 & 0.35 & 0.37 & 0.31 & 0.45 \\
\hline Mixed1 & 13.92 & 10.20 & 12.74 & 14.12 & 0.36 & 0.21 & 0.34 & 0.43 \\
\hline N.A.A & 11.43 & 10.29 & 11.78 & 14.02 & 0.44 & 0.42 & 0.43 & 0.42 \\
\hline Sucrose & 12.09 & 11.70 & 13.16 & 13.89 & 0.29 & 0.22 & 0.27 & 0.40 \\
\hline Yeast & 12.18 & 10.30 & 13.19 & 12.62 & 0.24 & 0.26 & 0.26 & 0.24 \\
\hline Mixed2 & 10.36 & 9.40 & 11.36 & 11.37 & 0.39 & 0.32 & 0.34 & 0.21 \\
\hline M1+M2 & 9.56 & 10.66 & 10.65 & 10.18 & 0.33 & 0.31 & 0.33 & 0.16 \\
\hline Ave. & 11.07 & 10.66 & 13.66 & \multicolumn{7}{|c|}{0.34} & 0.34 & 0.34 & \\
\hline LSD 0.05 & \multicolumn{3}{|c|}{$\mathrm{A}=0.33, \mathrm{~B}=0.83, \mathrm{AB}=1.40$} & $\mathrm{~A}=0.001, \mathrm{~B}=0.001, \mathrm{AB}=0.003$ \\
\hline
\end{tabular}

some compound as foliar application on grain yield and phytic acid conconteration of Faba bean plants.

$A=$ mineral, FYM, mixed treatments $\quad B=$ Treatments(foliar application)

$\mathrm{AB}=$ Interactions

\section{Phytic acid concenteration:}

The effect of tested variables on phytic acid (\%) for faba bean grain yield on the average of two growing seasons is presented in Table 2. The results reveal that data of $N, P, K$ treatment gave the heighest means value and their values were significant.

Average phytic acid (\%) for the mineral.-N, FYM and their combination treatments were equal $=0.34 \%$. The foliar application for mixed 1 treatment gave the highest mean values of phytic acid (\%), but the lowest mean values obtained by foliar application of mixed 2 treatment, speiesy yeast treatment $=$ $0.24 \%$.

The foliar application $(\mathrm{N}, \mathrm{P}, \mathrm{K})$ with in organic , organic- $\mathrm{N}$ and their combinations are the best treatment, because reduce phytic acid (\%) of bean seeds.

The results are in harmony with that obtained by Raboy et al., (2000) and sandberg, (2002).

\section{Macro nutrients uptake :}

The effect of Foliar application treatments with inorganic \& organic-N fertilizers and their combination on the macronutrients uptake of $\mathrm{N}, \mathrm{P}$ and $\mathrm{K}$ $(\mathrm{kg} / \mathrm{Fed})$ is peresnted in Table 3 . Results showed that the parameters under investigation increased significantly for the previous treatments.

The $(N, P, K)$ treatment gave the higher mean values for $N, P$ and $K$ uptake than the other treatments. 
Table 3 : Effect of inorganic \& organic-N and combined fertilizers with some compound as foliar application on $\mathrm{N}, \mathrm{P}$ and $\mathrm{K}$ - contents $(\mathrm{kg} / \mathrm{fed})$ of Faba bean plants.

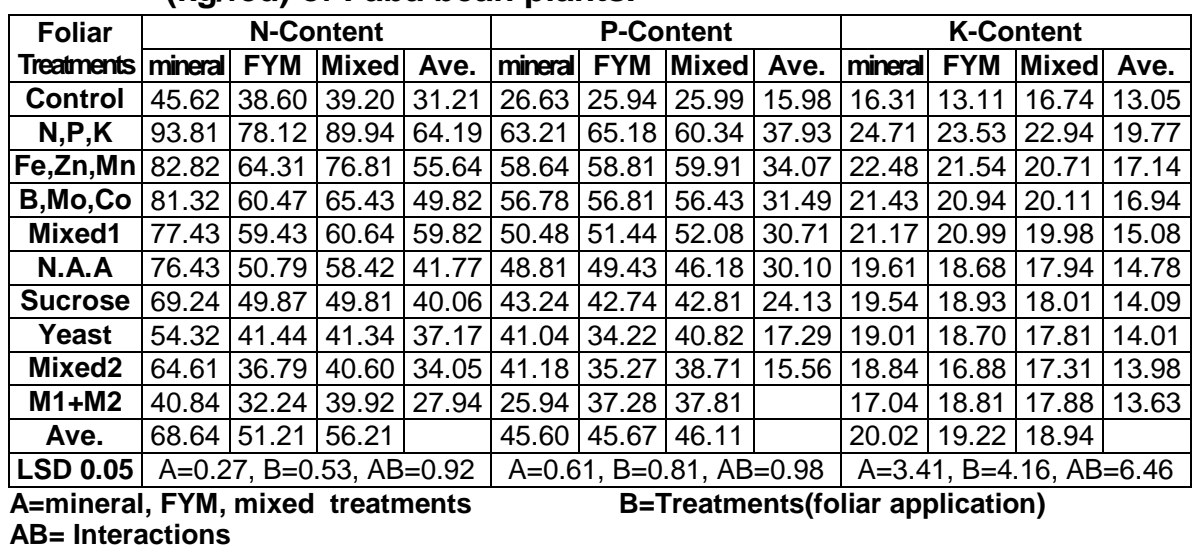

The highest $\mathrm{N}$ and $\mathrm{K}$-uptake was obtained from inorganic fertilizers, but the highest P-uptake was obtained from combined treatment.

The obtained results are confimerd. with results of Brohi and Karaman, (1997), Hag and Mallarino, (1998) and Janeczek et al., (2004).

It was cleared that, using mixing treatments not gave any effect in this trails as affected on N, P and $\mathrm{K}$ content .

Generally, the results referred to that the treatment of foliar (N, P and $\mathrm{K}$ ) foliary with inorganic fertilizers increased $\mathrm{N}$ and K-uptake over the control (55.36 and 33.99\%) respectively, but P-uptake over the control $(56.93 \%)$ of their combined fertilizer.

\section{Micro nutrients uptake:}

\section{$\mathrm{Fe}, \mathrm{Zn}$ and M-uptake:}

The effect of tested variables on $\mathrm{Fe}, \mathrm{Zn}$, and $/ \mathrm{Mn}$ content of Faba bean seeds for the two growing seasons is presented in Table 4, results reveal that there was significant effect of the foliar application treatments on $\mathrm{Fe}, \mathrm{Zn}$ and Mn-uptake.

The treatment of $(\mathrm{N}, \mathrm{P}, \mathrm{K})$ gave the highest mean values of $\mathrm{Fe}, \mathrm{Zn}$ and $\mathrm{Mn}$ uptake compared with other treatments. The average of mineral treatment gave the highest mean values for Fe uptake compared by FYM treatment, and mixed treatments values, respectively. But the organic treatment (FYM) gave the highest mean value for $\mathrm{Zn}$ uptake compared with mineral and mixed treatment, respectively. Results showed the averages were 20.15 and $9.96 \%$ less than the Fe-uptake of the inorganic-N fertilizer, while, were 1.65 and $9.92 \%$ less than the Zn-uptake of the organic-N fertilizer, otherwise, were 20 and $11 \%$ less than the $\mathrm{Mn}$ - uptake of the its combined fertilizer with the foliar treatment (N,P and $K$ ) which gave the highest mean values of $\mathrm{Fe}, \mathrm{Zn}$ and $\mathrm{Mn}$ - uptake.. These results are confirmed with results obtained by Thalooth et al., (2006), El-Banna and Abd El-Salam (2005) and Reddy and Shiv (2003). 
Abd El-Hameed, A.M. and S.H. Sarhan

T4-5

9200 
From this Table, using N.A.A, sucrose and yeast and mixed them, have no effect in Fe, $\mathrm{Zn}$ and Mn uptake .

Date presented in Table 5 , showed that the B, Mo and Cu uptake by faba bean seeds $\left(\mathrm{gmFed}^{-1}\right)$ were significantly increased by foliar application treatments with inorganic \& organic- $\mathrm{N}$ and their combined fertilizers compared to control, in the two seasons.

Also, results reveal that there were significant differences in B, Mo and Co uptake due to inorganic \& organic- $\mathrm{N}$ and their combined fertilizers. Average B-uptake from FYM and its combined fertilizers were, $14.53 \%$ and $16.81 \%$, less than that of mineral treatment, respectively. On the other hand, average Mo-uptake from mineral from mineral and its combined fertilizers were 19.60 and $13.77 \%$ less than that of FYM fertilizer. But for Cu-uptake equal for perovius addition for mineral, and FYM treatment.

From these results, it could be concluded that, using combined fertilizer ( $25 \%$ of mineral recommended dose $+25 \%$ of FYM recommended dose) with ( $\mathrm{N}, \mathrm{P}$ and $\mathrm{K}$ ) as foliar application to bean seeds helping to increase yield, macro and micronutrients.

The heighest B-uptake value (35.20) was obtained mixed treatment on mineral plots, while the heighest values for Mo-uptake was obtained from yeast on FYM causing raising in co-uptake values $(0.42)$ ( for mineral plots.

\section{REFERENCES}

Abd El-Hadi, A.H.; K.G. Asy; H.W. Doeriny; M.S. Kader; Y.H. Mohamed; A.A. Moustafa; M.E. Taha and A. Alexander (1986) : Effect of foliar fertilization on crops under Egyptian Conditions. Foliar Fertilization Developments in Plant and Soil Sci. Dordrecht Netherlands, Marthinus Nijhoff Publishers. PP. 126-141.

Abd El-Hameed; A.M; Mohamed M.R and Sarhan S.H.; (2003) Effect of micronutrients application on growth, yield and mineral composition of broad bean on saline soil. J. Agric. Sci. Mansoura Univ., 3:211-217.

Aly, M.S.; (2003) Effect of organic fertilizer and / or some percentage of NPK fertilizer on Fennel plants. J. Agric. Sci. Mansoura Univ., 28(4) : 32153226.

Black, C.A., (1982) : "Methods of Soil Analysis" part 2 American Society of Agronomy, Inc . Publisher, Madison, Wisconsin, USA.

Brohi, A.R. and M.R. karaman, (1997) : Effect of potassium and magnesium Fertilization on yield and nutrient content of rice crop grown on artificial Siltation soil. Turk. J. Agric. 24(2000) : 429-435.

Buttery B.R.; S.J. Parj and D.J. Hume (1992) : Potential for increasing nitrogen Fixation in grain Legumes. Can. J. Plant Sci., 72:323-349.

El-Banna, E.N. and H.Z. Abd El-Salam, (2005) : Response of potato plants for different sources of potassium with different foliar rates of boron and molybdenum. Plant Nutrition Dep., Soil, Water and Env, Res. Inst.; Agric. Res. Center, Giza, Egypt. 
Fathy, E.S.L. and Farid S.; (1996) : The possibility of using vitamins Bs and Yeast to delay senescence and improve growth and yield of common bean. J. Agric. Mansoura Univ., 21(4) : 1415-1423.

Gomez K.A and A.A. Gomez, (1984) : "Statistcal Procedures for the Agricultural Researches" Jhon Wiley and Sons, Inc., New York.

Hag, U. and Mallarino A.P., (1998): foliar fertilization of soybean at early vegetative stages. Agron. J. $90: 763-769$.

Irshad, M.T. Honna, A.E. Eneji and S. Yamamoto (2002) : Wheat response to nitrogen source under saline conditions. J. Plant nutrition, 25 (12): 2603-2613.

Janec Zek E.; K. Otecki A.; and M. Kozak (2004) : Effect of foliar fertilization with micronutrients on common bean. devetopment and seed yielding. Electronic journal of Polish Agricultural Univ. 7(1) : 21-42.

Mourad, A.K.; S. A. Hammed.; G. Z. Guriguis.; O. A. Zaghloul.; and H. A. Sadek (2004) : Action of some micronutrients on the infesteation and yield components of Faba bean. Aphid. Commun Agric. Appl. Biol. Sci., 69.,(3) : 291-304.

Omar, R, A.; A.A. daif; A. Sidaros and S.A. El-Kewery (1990) Abroad bean strain virus broad bean plant in Egypt. Agric. Res. Rev., 68(3) : 563562.

Raboy Victor, Willian F.S. and David S.E. (2000) : Origin and seed phenotype of maize low phytic acid 1-1 and low phytic acid 2-1. Braz J. Plant Physoil. 14 (1).

Reddy D. T and A. Shiv Raj (2003) Cobalt nutrition of ground nut in relation to growth and yield. J. of Plant and Soil. 42(1) : 145-152.

Resmi, R. and T. R. Gopolokrishnan; (2004) : Effect of plant growth regulators on the performances of yard long bean. J. Tropical Agriculture 42(1) : 145-152.

Sandberg A. S (2002) : Bioavoilability of minerals in Legumes. British J. Nutrition. 88( 3):5281-5285.

Sherif Fatma A. (2003). Effect of Foliar : sprays of multi-nutrient materials and $\mathrm{N}$-Fertilization on symbiotic performance of Bradyrhizobium japonicum, growth and yield of soybean. J. Agric. Sci. Mansoura Univ. 28(7) : 5661-5668.

Thalooth, A.T.; M.M. Tawfik and H. Magda Mohamed, (2006) : A Comparative study on the effect of foliar application of Zinc, Potassium and magnesium on growth, yield of Mnug bean plants grown under water stress conditions. World J. Agric. Sci., 2(1) : 37-46.

Tolba, M.H.; G.A. Baddour and A.M. El-Ghamry, (2003) : Effect of different sources of organic manure on Eggplant and some soil properities. J. Agric. Sci. Mansoursa Univ., 3:127-135.

Wheeler and Ferrel (1971): "A method for Phytic Acid Determination". Cer Chem. Book. 
إستجابة الفول البلدي للتسميد النيتروجيني المعدني والعضوي والتفاعل بينهم مـع

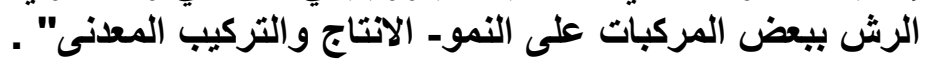

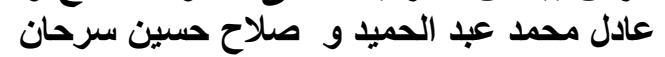

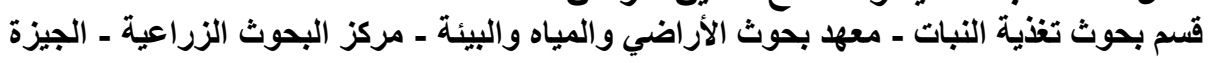
- مصر.

أجريت تجربتان لموسمي 2007/2006 - 2008/2007 في محطة البحوث الزر اعيـة

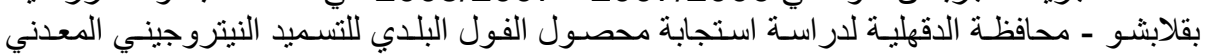

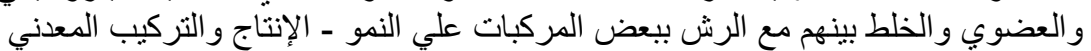

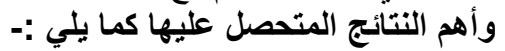

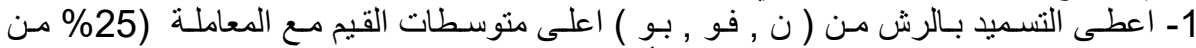

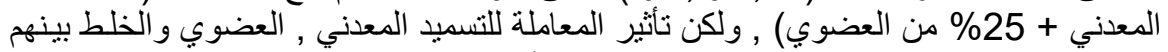
كان متساويا لمتوسطات القيم لتركيز حامض الفيايتك أسد , وكانت مع المعاملة (ن , فو , بو ) التي لئ أضيفت رشا.

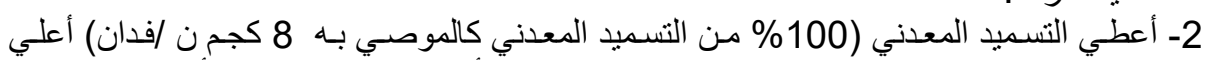

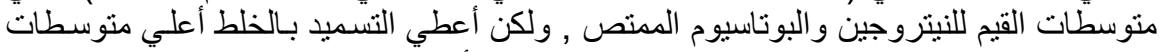

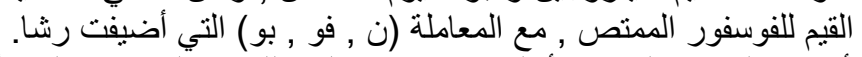

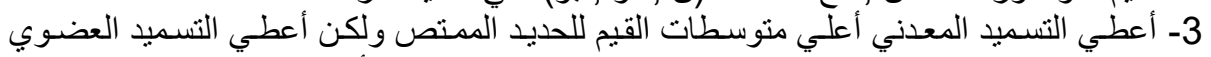

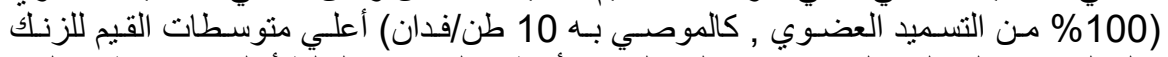

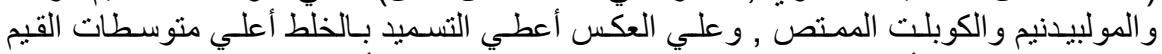

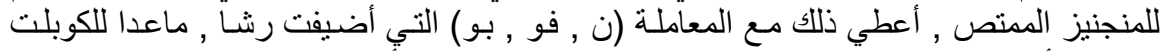

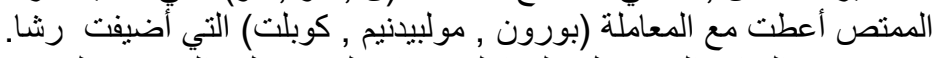

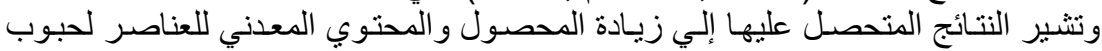

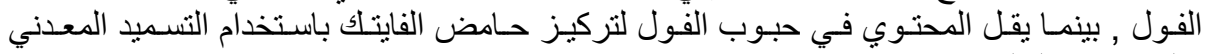
و العضوي و الخلط بينهما مع الإضافات رشا. 
Table 4: Effect of inorganic \& orgnic- $\mathrm{N}$ fertilizer and its combination fertilizers with some compound as foliar application on Fe, $\mathrm{Zn}$ and $\mathrm{Mn}$ - contents (gm/fed) of Faba bean seeds.

\begin{tabular}{|c|c|c|c|c|c|c|c|c|c|c|c|c|}
\hline \multirow{2}{*}{$\begin{array}{c}\text { Foliar } \\
\text { Treatments }\end{array}$} & \multicolumn{4}{|c|}{ Fe-uptake } & \multicolumn{4}{|c|}{ Zn-uptake } & \multicolumn{4}{|c|}{ Mn-uptake } \\
\hline & mineral & FYM & Mixed & Ave. & mineral & FYM & Mixed & Ave. & mineral & FYM & Mixed & Ave. \\
\hline Control & 1356 & 784 & 768 & 943.30 & 400 & 380 & 320 & 380 & 70 & 48 & 56 & 60.67 \\
\hline $\mathbf{N}, \mathbf{P}, \mathbf{K}$ & 3618 & 2058 & 2994 & 2039.18 & 964 & 943 & 627 & 820.80 & 134 & 204 & 228 & 164.68 \\
\hline Fe,Zn,Mn & 2944 & 2282 & 2256 & 1986.10 & 912 & 834 & 512 & 561.45 & 142 & 178 & 178 & 160.87 \\
\hline $\mathrm{B}, \mathrm{Mo}, \mathrm{Co}$ & 2442 & 3170 & 2538 & 193 & 691 & 679 & 634 & 539 & 106 & 180 & 160 & 123.07 \\
\hline Mixed1 & 2855 & 1428 & 1842 & 1903 & 599 & 648 & 674 & 501.01 & 196 & 126 & 186 & 122.88 \\
\hline N.A.A & 1898 & 1134 & 1302 & 1698 & 592 & 699 & 508 & 486.40 & 162 & 170 & 154 & 116.13 \\
\hline Sucr & & 2568 & 2082 & 162 & & 587 & 559 & 470 & 170 & 160 & 142 & 115.90 \\
\hline Yeast & 368 & 1842 & 1656 & 1352.50 & 505 & 480 & 508 & 436.16 & 94 & 114 & 84 & 112.21 \\
\hline Mixe & 32 & 1116 & 2076 & $121 \varepsilon$ & 417 & 480 & 487 & 412.11 & 104 & 66 & 102 & 112.18 \\
\hline M1+ & 2034 & 1230 & 2460 & & & 324 & 630 & 372.40 & 68 & 130 & 100 & 102.91 \\
\hline Ave. & 2218.10 & 1771.11 & \begin{tabular}{|l|}
1997.18 \\
\end{tabular} & & 604 & 605.40 & 545.90 & & 124.60 & 137.60 & 155.0 & \\
\hline LSD 0.05 & $A=$ & $1.13, B=$ & $1.66, \mathrm{AB}=$ & & & $=0.50, \mathrm{~B}=$ & $21, A B=$ & & & $18, B=$ & $42, A B=$ & \\
\hline
\end{tabular}

$\mathrm{A}=$ mineral, $\mathrm{FYM}$, mixed treatments

$\mathrm{B}=$ Treatments(foliar application)

$\mathrm{AB}=$ Interactions

Table 5: Effect of inorganic \& organic $-\mathrm{N}$ and combined fertilizers with some compounds foliar application on B, Mo and Co contents (gm/fed) of Faba bean plants.

\begin{tabular}{|c|c|c|c|c|c|c|c|c|c|c|c|c|}
\hline \multirow{2}{*}{$\begin{array}{c}\text { Foliar } \\
\text { Treatments }\end{array}$} & \multicolumn{4}{|c|}{ B- uptake } & \multicolumn{4}{|c|}{ Mo- uptake } & \multicolumn{4}{|c|}{ Co- uptake } \\
\hline & mineral & FYM & Mixed & Ave & mineral & FYM & Mixed & Ave & mineral & FYM & Mixed & Ave \\
\hline Control & 13.40 & 11.12 & 12.40 & 11.49 & 4.40 & 4.10 & 3.80 & 2.49 & 0.24 & 0.14 & 0.12 & 0.17 \\
\hline N,P,K & 10.40 & 11.30 & 28.80 & 22.20 & 4.00 & 12.30 & 10.80 & 7.78 & 0.18 & 0.18 & 0.28 & 0.21 \\
\hline Fe,Zn,Mn & 18.40 & 15.20 & 24.80 & 18.18 & 4.20 & 7.40 & 9.30 & 7.17 & 0.24 & 0.30 & 0.25 & 0.26 \\
\hline $\mathrm{B}, \mathrm{Mo}, \mathrm{Co}$ & 28.00 & 30.10 & 24.20 & 18.01 & 8.80 & 12.80 & 13.80 & 7.06 & 0.36 & 0.54 & 0.41 & 0.44 \\
\hline Mixed1 & 35.20 & 24.00 & 22.00 & 17.83 & 7.60 & 8.20 & 5.40 & 6.72 & 0.36 & 0.24 & 0.30 & 0.30 \\
\hline N.A.A & 16.00 & 12.20 & 14.30 & 13.71 & 4.80 & 4.60 & 5.10 & 4.15 & 0.18 & 0.12 & 0.14 & 0.14 \\
\hline Sucrose & 24.80 & 33.40 & 25.90 & 13.07 & 6.40 & 10.10 & 13.80 & 4.03 & 0.42 & 0.40 & 0.21 & 0.34 \\
\hline Yeast & 26.40 & 13.40 & 15.10 & 12.94 & 4.10 & 18.20 & 9.40 & 4.01 & 0.30 & 0.24 & 0.26 & 0.26 \\
\hline Mixed2 & 20.00 & 12.20 & 13.80 & 12.80 & 5.10 & 4.80 & 4.60 & 3.99 & 0.18 & 0.19 & 0.10 & 0.15 \\
\hline M1+M2 & 9.60 & 9.90 & 17.30 & 11.69 & 6.40 & 11.80 & 5.30 & 3.97 & 0.18 & 0.16 & 0.14 & 0.16 \\
\hline Ave. & 20.23 & 17.29 & 19.89 & & 7.59 & 9.44 & 8.14 & & 0.25 & 0.25 & 0.22 & \\
\hline LSD 0.05 & \multicolumn{4}{|c|}{$\mathrm{A}=0.10, \mathrm{~B}=0.10, \mathrm{AB}=0.27$} & \multicolumn{4}{|c|}{$\mathrm{A}=0.08, \mathrm{~B}=0.02, \mathrm{AB}=0.03$} & \multicolumn{4}{|c|}{$\mathrm{A}=0.33, \mathrm{~B}=0.44, \mathrm{AB}=0.76$} \\
\hline
\end{tabular}

$A=$ mineral, FYM, mixed treatments $\quad B=$ Treatments(foliar application)

$\mathrm{AB}=$ Interactions 
